\title{
Exposure of Murattal Al-Quran Audio Enhances Cisplatin Activity on Growth Inhibition and Cell Cycle Modulation on Hela Cells
}

\author{
Roihatul Mutiah' ${ }^{1}$ Muhammad Ragib Mustafa ${ }^{1}$, Yen Yen Ari Indrawijaya ${ }^{1}$, Abdul Hakim ${ }^{1}$, \\ Rahmi Annisa ${ }^{1}$, Nurlaili Susanti ${ }^{2}$, Ach Nashichuddin², Muhammad Zainuddin ${ }^{3 *}$ \\ ${ }^{1}$ Department of Pharmacy, Faculty of Medicine and Health Sciences, Maulana Malik Ibrahim State Islamic University, \\ Malang, Indonesia \\ ${ }^{2}$ Study Program Medical Studies and Medical Profession, Faculty of Medicine and Health Sciences, Maulana Malik \\ Ibrahim State Islamic University, Malang, Indonesia \\ ${ }^{3}$ Faculty of Tarbiyah and Teaching Training, Maulana Malik Ibrahim State Islamic University, Malang, Indonesia
}

\begin{abstract}
Cancer is a disease characterized by abnormal cell mechanisms. The development of alternative cancer treatments is still needed. One of them is the music therapy. The music therapy uses sound vibrations to improve healing. Al-Quran, the Holy book of muslims, recites with measured recitation produces beautiful tones. Reading and recitating of AlQuran is an important form of worship for which a Muslim can expect reward and benefit in the Hereafter. Al-Fatihah is one of surahs in Al-Qur'an that is often read by Muslims and used as a prayer for healing. The purpose of this study was to determine the effect of cytotoxic activity and cell cycle modulation on Hela cells with exposure of murattal AlQuran and cisplatin combination. Audio exposure murattal Al-Fatihah and its combination with cisplatin to HeLa cells were tested using the MTT method assay. Induction of apoptosis and modulation of cell cycle evaluated by flow cytometry method. Treatment used 30 minutes Audio Murattal (AM), Cisplatin $10 \mu \mathrm{g} / \mathrm{mL}$ (Cis), and the combination of $\mathrm{AM}+\mathrm{C}$ is caused a decrease in the viability of HeLa cells respectively $80.14 \%, 69.86 \%$, and $64.32 \%$. The results of flow cytometry explained that in treatment of $A M$ there was inhibition in the G2-M phase and induction of apoptosis in the M5 phase. Whereas in treatment $A M+C$ is inhibition occurs in the S, G2-M phase, and induction of apoptosis in the M5 phase. Audio Murattal Al-Quran presents cytotoxic effects on HeLa cells and to provide a synergistic impact on cisplatin so that disclosure therapy murattal can be recommended for supporting therapy in the treatment of cancer (supportive therapy).
\end{abstract}

Keywords: Al-Quran, Audio murottal, HeLa Cells, Cell Viability, Flow cytometry

\section{INTRODUCTION}

Al-Quran as shifa can cure human diseases. The method of Quranic medicine is a cure for physical ailment such as cancer and heart problems which using the Quranic verses via reading and hearing (murottal) by the patient (Ibrahim, et al., 2016). A previous study was evaluate the effect of murottal Al-Quran B-cell lymphoma 2-like

Submitted: April 9, 2019

Revised: June 15, 2019

Accepted: June 18, 2019

*Corresponding author: aldin_uin@yahoo.com 
12 (BCL2L12) gene expression of PC-3 (human epithelial teratocarcinoma) cells and have positive effects on the cancerous cells (Mehrafsar and Mokhtari, 2018). Another study revealed that audible sound for healing was able to alter the cell cycle, morphology, and functional parameter in non -auditory human cells (Sundarajan, et al., 2014).

Cancer is the second leading cause of death contributing $13 \%$ of deaths from $22 \%$ of deaths from major non-communicable diseases in the world (Oemiati, et al., 2011). Cancer is a disease characterized by abnormal and uncontrolled mechanisms for regulating cell survival, proliferation and differentiation. If the spread of cancer not controlled it can cause death (Hondermarck, 2003). Cells which are abnormal in certain parts of the body grow out of control and can attack other tissues to form other cancer cells. The abnormal cells befall in the cervical region, which is then known as cervical cancer (Prabasari and Budiana, 2017).

The cancer treatment methods currently being implemented are surgery, radiation, and chemotherapy. These medical treatment for cancer have a variety of predicaments such as side effects, resistance, high medical costs, and complications (Nisyak and Rahman, 2017). Chemotherapy is commonly used and is the first line chemotherapeutic agent for the treatment of cervical cancer, namely cisplatin. However, regular use of cisplatin can cause serious side effects (Yudhani, et al., 2016).

The development of chemopreventive agents that can slow or prevent the growth of cancer cells originating from natural materials has been widely carried out (Ismiyati and Nurhaeni, 2016). Nevertheless, herbal medicines considered safe when employed singly at recommended doses and times, conventional drug interactions with herbs can cause serious side effects or treatment failure (Putri and Rusdiana, 2016). As for cancer treatment, a single therapy from herbal medicine is still not recommended. Therefore, alternative therapies needed for cancer that does not have the risk of treatment failure when combined with conventional medicine as first-line therapy. The devel- opment of alternative therapies for cervical cancer in addition to natural ingredients continues, one of them is sound therapy. Sound treatment is using frequency vibrations or audio forms combined with music or musical elements (rhythm, melody, harmony) to improve healing (Djohan, 2006). Fabien Maman (1997) noted that cancer cells become unstable and disintegrate (destroyed) when listened to all musical notes on a scale of 3040 decibels (Maman, 1997; Heather, 2007). Previous research showed that music (Beethoven, Ligeti, and Mozart) tested on MCF-7 (human breast adenocarcinoma cell line) breast cancer cells can affect cell cycle, proliferation, viability, and binding of hormones to their targets (Lestard, et al., 2013). Previous studies have also reported that acoustic vibrations in MCF-7 and MDA-MB-231 (isolate at M $\mathrm{D}$ Anderson from a pleural effusion of a patient with invasive ductal carcinoma) cells can stop cell growth and induce cell death (Lestard and Capella, 2016).

In cancer therapy research, a beautiful musical approach as an ingredient connected with the beauty of the rhythm of reading Al-Quran, which recited in measured recitation (Murattal). Khatoni (1997) mentions that harmonious tones of Al-Quran are a type of music that is full of secrets. Al-Quran contains proper consistency which not found in the human books. The words and letters included in the Al-Quran have a perfect order (Al-Kaheel, 2012).

Surah Al-Fatihah is one of the surah in the Al-Quran which consists of seven verses, always read repeatedly by every Muslim day and night, at least seventeen times. Imam Al-Qurthubi in his commentary says "In the Surah Al-Fatihah there are characteristics which not found in other surahs. To the extent that it said that all the contents of the Al-Quran contained in it. Contains twenty-five words that include the entire Al-Quranic science (Al-Qurthubi, 2006 in Sayyid, 2008). The sound therapy approach between music and the Qur'an, especially the surah Al-Fatihah is a reference for this research. At the therapy supportive for cervical cancer, this study also tested a combination of audio murattal (AM) with cisplatin (Cis) 
as the first line in the treatment of cervical cancer. This study aims to discover the impact of exposure audio murattal (AM) surah Al-Fatihah and its combination with cisplatin (AM + Cis) against inhibition of HeLa cancer cell growth and cycles.

\section{MATERIALS AND METHODS}

\section{Cell Culture}

HeLa Cells obtained from the Cancer Chemoprevention Research Center (CCRC) Faculty of Pharmacy, Gadjah Mada University. HeLa cells were grown on RPMI 1940 medium (Gibco, Invitrogen cell culture, Carisbad, USA) and incubated in $\mathrm{CO} 2$ incubators (Thermo Heraeus, Heracell, Langenselbold, Deutschland). Cells were harvested with $0.25 \%$ trypsin-EDTA media (Gibco, Invitrogen cell culture, Carisbad, USA) when the number of cells in the culture dish reached $80 \%$ confluently.

\section{Treatment with Audio Murattal}

The HeLa cells were given 30 minutes of exposure murattal surah Al-Fatihah read by Syaikh Misyari Rasyid from audio Bluetooth speaker (JBL, Los Angeles, USA) with measured range level frequency $16 \mathrm{~Hz}-8 \mathrm{kHz}$ and range level intensity $15-$ $63 \mathrm{db}$ (Audacity Software). The exposure of murattal surah Al-Fatihah also exposed to HeLa cells which are given a dose of cisplatin (Wako Pure Chem-ical Industries, Osaka, Japan) $10 \mu \mathrm{g} / \mathrm{mL}$ as the test combination. Exposure is carried out in a glass box in the laboratory room. The cell is exposed to a sound murattal using a speaker located symmetrically with a plate for 30 minutes (Lestard, et al., 2013; Lestard and Capella, 2016). Cells that are not detected are put into a soundproof incubator, so they are not exposed to sound (silence).

\section{Microtetrazolium (MTT) Assay}

MTT Assay is one method for determining cell numbers. Twenty-four hours after treatment, the cell media was removed and washed with phosphate buffer saline (PBS) pH 7.4 which is made by dissolving $0.2 \mathrm{~g} \mathrm{KCl}$ (for molecular biology, Sigma Aldrich, Germany), $8 \mathrm{~g} \mathrm{NaCl}$ (for molecular bi- ology, Sigma Aldrich, Germany), $1.15 \mathrm{~g} \mathrm{Na}_{2} \mathrm{HPO}_{4}$ (for molecular biology, Sigma Aldrich, Germany), and $\mathrm{KH}_{2} \mathrm{PO}_{4}$ (for molecular biology, Sigma Aldrich, Germany) in 1 liter distilled water. Provision of MTT reagents (3-[4,5-dimethylthiazol-2-yl]-2,5 diphenyl tetrazolium bromide) (Sigma Aldrich, Germany) as much as $100 \mu \mathrm{L}$ to each well, including media control (without cells), then incubated again for 2-4 hours inside $\mathrm{CO} 2$ incubator (Thermo Heraeus, Heracell). Incubation is done until formazan formed with a inverted microscope (Carl Zeiss Axiovert 25, Jena, Germany). If formazan, then added stopper of $100 \mu \mathrm{L}$ SDS 10\% (Merck-Schuchardt \& Co D-85662 Hobenbrunn, Germany) is in $0.01 \mathrm{~N} \mathrm{HCl}$ (Merck, Darmstadt, Germany). The 96-well plate (Iwaki, Yatomi, Japan) are wrapped in paper or aluminium foil and incubated in a dark place at a room temperature overnight (not in an incubator). Reading the absorbance value using ELISA reader (BioRad microplate reader Benchmark serial no.11565, Fukuoka, Japan) is done after the cell is left alone for one night. Readings of each well with ELISA reader at $595 \mathrm{~nm}$. The absorbance value is calculated to determine the percentage of cell viability.

\section{Flow Cytometry}

The cell cycle state is evaluated using the method Flow Cytometry (Lestard, et al., 2013). Twenty-four hours after treatment with silent and murattal sound, the cells were washed with PBS and harvested with trypsin-EDTA $0.25 \%$ (Gibco, Invitrogen Canada). The conical tube (Falcon) is centrifuged (Maxi Mix II, Thermolyne type 37600 mixer, Iowa, USA) at a speed of $2000 \mathrm{rpm}$ for 5 minutes. The supernatant was removed and added $500 \mathrm{~mL}$ of $70 \%$ alcohol to fix cells. Steril eppendorf (Plasti Brand) stored at a room temperature $37 \mathrm{oC}$ for 30 minutes. After incubation, ethanol removed and cells washed with PBS. Then flow cytometry reagent $(25 \mu$ propidium iodide, $25 \mu 1$ RNase, $0.5 \mu 1$ Triton-X in $500 \mu 1$ PBS) was added and left for 30 minutes. The cell suspension is transferred into flow cytometry-tube. Flow cytometry-tube is read with the flow cytometer cell analyzer (FACS-Calibur, Bioscience US) to find out profiles cell cycle. 


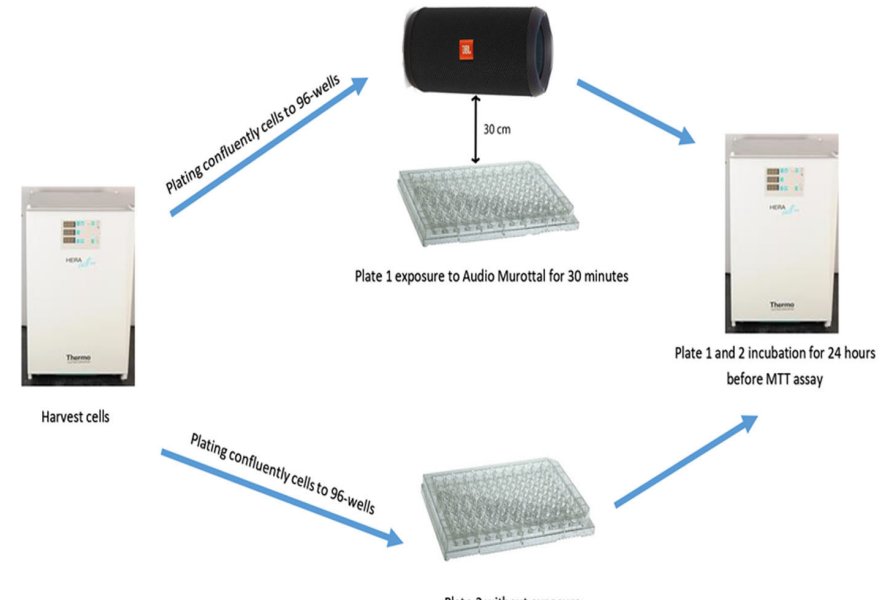

Plate 2 without exposure

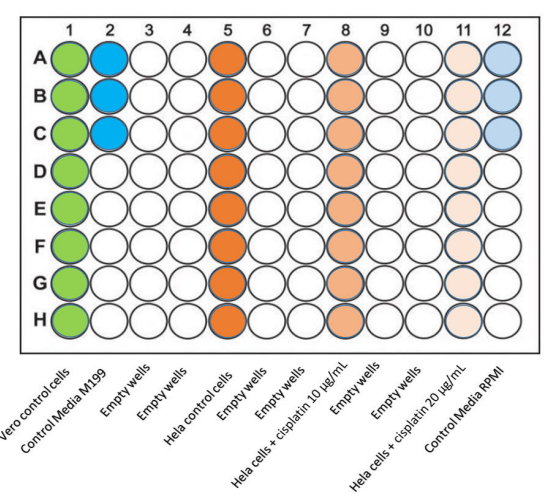

Template 96-wells for Plate 1 and 2

Figure 1. Treatment with Audio Murottal scheme. Hela cells $\left(5 \times 10^{5}\right.$ cells/well) were planted in 96 -well plate and $24 \mathrm{~h}$ after plating, the cells were harvested and confluently. Then media control for each plate was throw away and added (cisplatin $10 \mu \mathrm{g} / \mathrm{mL}$ ) and control media RPMI. The plate 1 was given 30 minutes exposure of audio murottal then incubation for $24 \mathrm{~h}$ before MTT assay, while plate 2 incubation for $24 \mathrm{~h}$ before MTT assay.

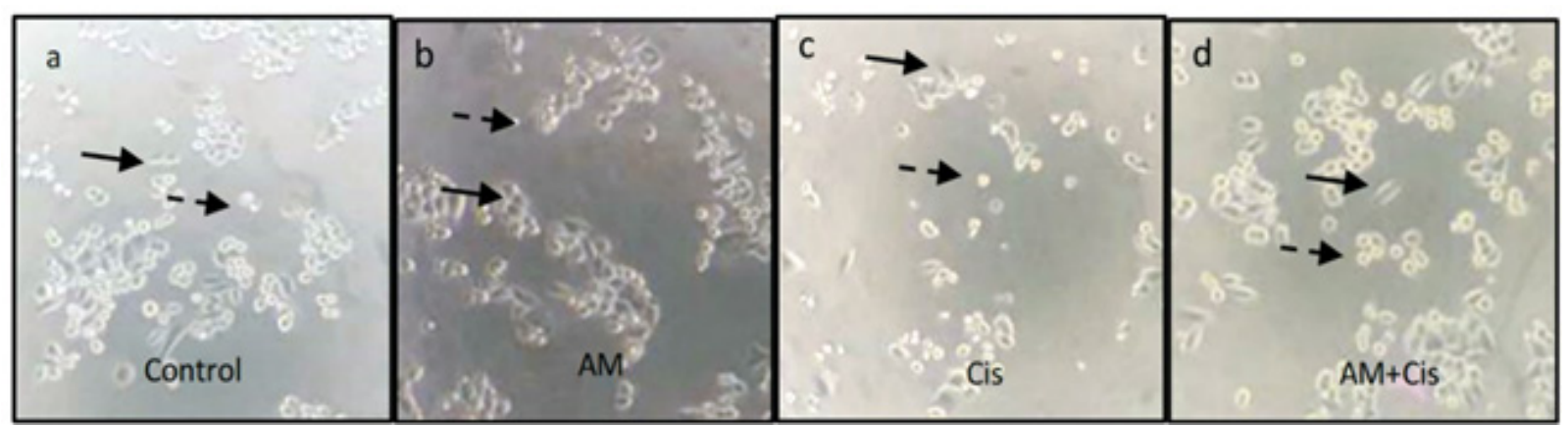

Figure 2. MTT assay result of cell culture after treatment (Scale bar: $10 \mu \mathrm{m}$ in 100x): (a) control; (b) Audio Murottal (AM) treatment; (c) Cisplatin treatment $10 \mu \mathrm{g} / \mathrm{ml}$ (Cis); combination treatment of $\mathrm{AM}$ and Cis. The sign -> indicates the viable cell, and The sign --> indicates the dead cell with morphological changes in the form of cell shrinkage, the cell becomes rounded, and there is no contact with neighboring cells (no contact inhibition). The percentage of cell viability is shown in Table 1. Percentage of viability AM, Cis, AM + Cis were $80.14 \% ; 69.86 \%$; and $64.32 \%$ respectively. These results indicate that exposure murattal Al-Fatihah can affect HeLa cell viability. 
Indonesian Journal of Cancer Chemoprevention, June 2019

ISSN: 2088-0197

e-ISSN: $2355-8989$

iscc. IIIJCLC

Table 1. Analysis of MTT Assay Results

\begin{tabular}{|c|c|c|c|c|c|c|c|c|}
\hline \multirow[b]{2}{*}{ Group } & \multicolumn{3}{|c|}{$\%$ Viability in triplicate } & \multirow[b]{2}{*}{$\begin{array}{l}\text { Average of } \\
\% \text { viability }\end{array}$} & \multicolumn{4}{|c|}{ p-value of Post-hoc Tukey Analysis } \\
\hline & 1st & 2nd & 3 rd & & $\begin{array}{l}\text { Hela } \\
\text { control } \\
\text { cell }\end{array}$ & $\begin{array}{c}\mathrm{AM} \\
\text { treatment }\end{array}$ & $\begin{array}{c}\text { Cis } \\
\text { treatment }\end{array}$ & $\begin{array}{l}\mathrm{AM}+\mathrm{C} \text { is } \\
\text { treatment }\end{array}$ \\
\hline $\begin{array}{l}\text { Hela Control cell } \\
\text { without } \\
\text { treatment }\end{array}$ & 100 & 100 & 100 & $100 \pm 0.000$ & - & 0.000 & 0.000 & 0.000 \\
\hline AM Treatment & 78.90 & 80.19 & 81.32 & $80.14 \pm 0.9895$ & 0.000 & - & 0.000 & 0.000 \\
\hline Cis Treatment & 70.18 & 69.86 & 69.53 & $69.86 \pm 0.2636$ & 0.000 & 0.000 & - & 0.000 \\
\hline $\begin{array}{l}\mathrm{AM}+\mathrm{Cis} \\
\text { Treatment }\end{array}$ & 64.37 & 64.04 & 64.32 & $64.53 \pm 0.2013$ & 0.000 & 0.000 & 0.000 & - \\
\hline
\end{tabular}
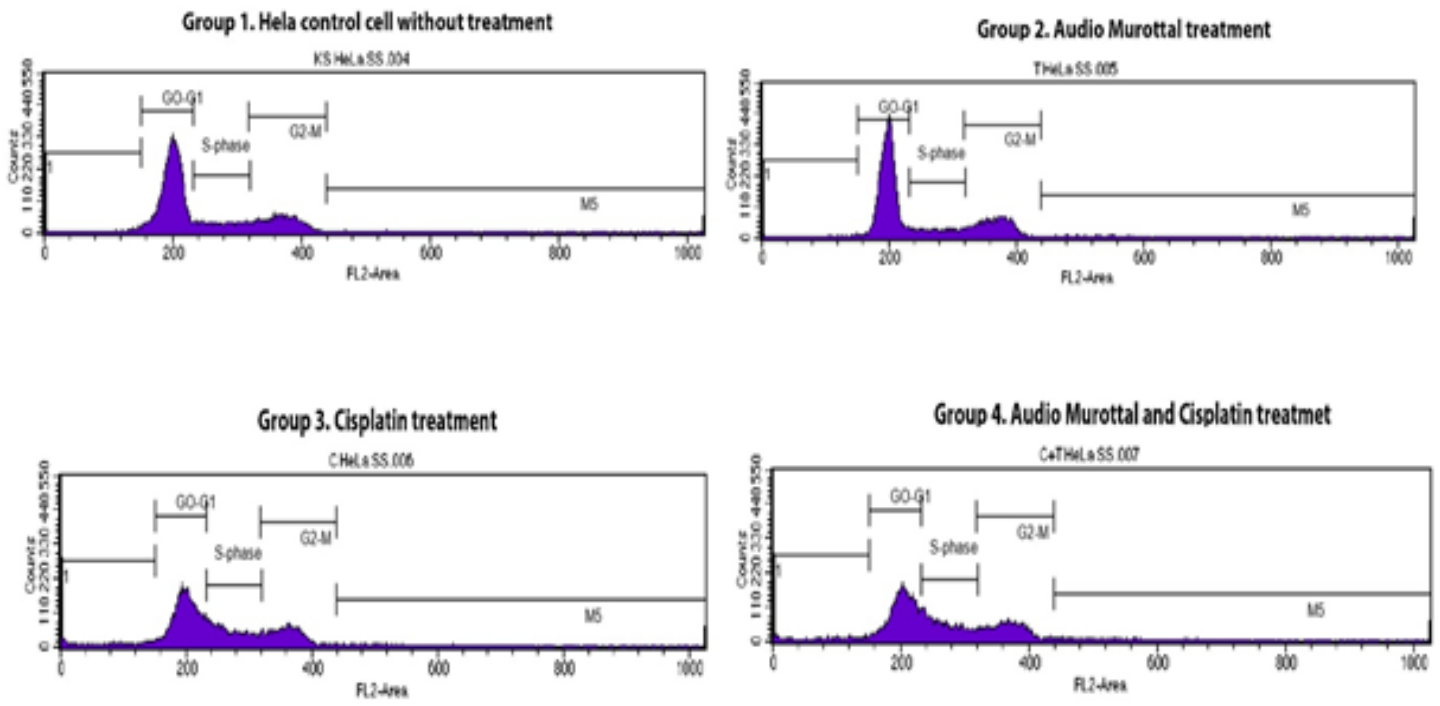

\begin{tabular}{|c|c|c|c|c|}
\hline \multirow{2}{*}{ Cell cycle phase } & \multicolumn{3}{|c|}{ \% Gated of each group } \\
\cline { 2 - 5 } & $\begin{array}{c}\text { Hela control cell } \\
\text { without treatment }\end{array}$ & AM Treatment & Cis Treatment & $\begin{array}{c}\text { AM + Cis } \\
\text { Treatment }\end{array}$ \\
\hline M1 & 7.55 & 6.54 & 14.42 & 13.84 \\
\hline G0-G1 & 55.38 & 54.71 & 40.44 & 37.09 \\
\hline S-phase & 13.36 & 11.27 & 21.57 & 22.19 \\
\hline G2-M & 20.26 & 22.01 & 19.04 & 20.72 \\
\hline M5 & 4.40 & 6.25 & 6.00 & 7.36 \\
\hline
\end{tabular}

Figure 3. Flow cytometry HeLa Cell Cycle result. Evaluation of profiles cell cycle after treatment Audio Murottal (AM), Cisplatin (Cis), and Audio murottal + Cisplatin ( $A M+C$ is) which seeded in 6-well plate and $24 \mathrm{~h}$ after plating. $\mathrm{AM}$, Cis, and $\mathrm{AM}+\mathrm{Cis}$ induced cell cycle arrest on cervical cancer Hela cells. After treatment $A M$ in the $M 1$ phase (Sub G1) obtained percentage gated $6.54 \%$ which lower than Hela cells control (4.40\%) means AM treatment has not induction cell cycle of Hela cell apoptosis. The accumulation of M5 (hyperploidi) phase between $C$ is $(6.00 \%)$ and $A M+C$ is $(7.36 \%)$ treatment showed inhibition accumulation that occurred before in G2-M phase and lead to apoptosis in $A M+$ Cis treatment higher than Cis. 


\section{RESULTS}

\section{Cytotoxic Test Results}

The results of exposure to audio murattal Al-Fatihah (AM) on HeLa cells can be seen in Figure 1. Healthy HeLa cells are oval and attach to the bottom of the well. In a treatment, AM appears to be a change in a cell morphology which is a sign of death cell. In the treatment $\mathrm{AM}+\mathrm{Cis}$ also showed the death cell. Morphological changes in dead cells are shrinkage (cell shrinkage) so that cells appear smaller changed to become rounded and lose contact inhibition.

\section{Analysis of cell Cycle and Apoptosis with method flow cytometry}

Audio Exposure murattal Al-Fatihah have an effect on HeLa cells and the combination with cisplatin shown in the figure. Reading the flow cytometry data is seen through the accumulation which occured in the cell cycle phase and compared with the control. Accumulation in certain phases indicates a phase of arrest (Handayani, et al., 2017; Da'i, et al., 2011). The AM treatment accumulated in the G2-M phase which means there is an inhibitory mechanism. The accumulation is followed by accumulation in the M5 phase. Treatment of AM + Cis inhibition mechanism happens in S, G2-M, and M5 phases. The accumulation of M5 (hyper ploidy) that previously accumulated in the G2-M phase shows the presence of induction of apoptosis (Da'i, et al., 2011).

\section{DISCUSSION}

\section{Cytotoxic Test with MTT Assay}

As a result of cytotoxic tests on HeLa cancer cells presented by audio Murattal Al-Fatihah (AM) for 30 minutes explicated cell viability of $80.14 \%$, whereas AM + Cis treatment gave a smaller percentage of cell viability $(64.32 \%)$ compared to Cis treatment $(69.86 \%)$. These results indicate the effect of inhibition of HeLa cell growth due to audio exposure murattal. Audio Murattal also provides a synergistic effect with cisplatin. This is supported by previous studies that showed if music (Beethoven, Ligeti, and Mozart) tested on MCF-7 breast cancer cells can affect cell cycle, proliferation, viability, and binding of hormones to their targets (Lestard, et al., 2013).

A possible mechanisms for the inhibition of HeLa cell growth due to audio exposure is murattal thought to be due to the influence of vibrations or mechanical vibrations. This is based on previous research which stated that the effect of sound on noncellsisauditory-relatedtomechanicalstresscausedby mechanical vibrations (Lestard and Capella, 2016).

\section{Cell Cycle Analysis and Apoptosis with Meth- ods Flow cytometry}

Decreasing cell viability designated two physiological events namely cell death (necrosis/apoptosis) and cell cycle inhibition (Larasati. et al., 2014). Therefore, further testing is implemented to determine the distribution of cell populations from the cell cycle process that occurs. Audio exposure Murattal Al-Fatihah, which was tested using the MTT method Assay, followed by testing using the method flow cytometry. The use of this method is done to define the cell cycle and apoptosis. Accumulation in the cell cycle is one of the primary targets of anticancer agents. Accumulation in certain phases indicates a phase of arrest (Handayani, et al., 2017; Da'i, et al., 2011). Treatment audio murattal (AM) for 30 minutes there was a G2-M mechanism arrest seen from the accumulation of cells compared to controls. Cell accumulation in G2-M arrest is ensued by cell accumulation in the M5 phase which indicates the presence of induction of apoptosis. Da'i (2011) stated that the accumulation in the M5 phase (hyper ploidy) that previously accumulated in the G2-M phase indicates the presence of induction of apoptosis.

Unlike the AM treatment, the Cis treatment is seen as a mechanism of arrest. Cell accumulation in this phase is more significant than the AM treatment. The results of this study are in line with 
previous studies where it known that the mechanism of action of Cisplatin was the same as that of an alkylator. This class of drugs kills cells in all their growth cycles, inhibits DNA biosynthesis and binds to cross-linking DNA. Cytotoxicity occurs at any stage of cell cycle development, but the most sensitive cells are the G1 and S phases. Not only the primary bond site is N7 in guanine, but also covalent bonds with adenine and cytosine are formed. In a high chloride plasma environment, cisplatin defines as a neutral type, which enters cells

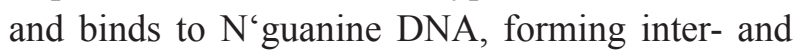
intra-cross cross-links. Cytotoxic lesions that inhibit DNA and RNA synthesis (Zhang, et al., 2001).

The combination treatment of audio exposure was murattal Al-Fatihah and cisplatin (AM + Cis) performed to determine the effect of these combinations on the HeLa cell cycle. The AM + Cis treatment inhibits the $\mathrm{S}$ and $\mathrm{G} 2-\mathrm{M}$ phases which are characterized by greater cell accumulation in this phase compared to the treatment of Cis. In addition to the cell cycle inhibition mechanism, the combination treatment of $\mathrm{AM}+\mathrm{C}$ is also induces apoptosis as indicated by cell accumulation in the M5 phase. Based on this, the combination treatment of AM + Cis is likely to occur synergistically between audio exposure murattal and cisplatin in cell cycle inhibition and apoptotic induction. The results of flow cytometry are supported by previous tests using MTT Assay which showed a cytotoxic effect from the combination of AM + Cis on HeLa cancer cells.

\section{CONCLUSION}

Exposure Murattal Al-Quran for 30 minutes can affect the HeLa cell cycle with a 24-hour incubation period that is inhibition in the G2-M phase and induction of apoptosis which is characterized by the accumulation in the M5 phase (hyper ploidy). The combination of exposure murattal Al-Quran with cisplatin $10 \mu \mathrm{g} / \mathrm{mL}$ also helps inhibit the $\mathrm{S}$ and G2-M phase of HeLa cells and induction of apoptosis with accumulation in the M5 phase.

\section{REFERENCES}

Al-Kaheel, A.D., 2012, Treatment of Qurani, Efficacious treatment with Al-Quran, [Translation] 'Alij Nafsaka bi Al-Quran. Translated by: Muhammad Misbah, Jakarta: AMZAH. Al-Qurthubi, 2006, Al-Jami' li Ahkamil Qur'an. 1st ed. Al Resalah Publishers, Beirut, 110-111.

Da'i, M., Supardjan, A.M., Jenie, U.A., Kawaichi, M. and Meiyanto, E., 2011, Pentagamavunon-1 inhibition T47D cell cycle caspase induced inhibitor Z-VAD-Fmk in G2-M phase, Indonesian Journal of Pharmacy, 5, 180-187.

DeFilippis, R.A., Goodwin, E.C., Wu, L., DiMaio, D., 2003, Endogenous Human Papillomavirus E6 and E7 Proteins Differentially Regulate Proliferation, Senescence, and Apoptosis in HeLa Cervical Carcinoma Cells, Journal of Virology, 77, 1551-1563.

Dharmayanti, N.L.P., 2003, Study of Molecular Biology: Tumor suppressor gen (p53) as target gen in cancer treatment, Wartazoa, 13, 99-107.

Djohan, 2006, Music therapy, theory and application, Yogyakarta: Galangpress.

Goodwin, E.C. and DiMaio, D., 2000, Repression of Human Papilloma Virus Oncogenes in HeLa Cervical Carcinoma Cells Causes the Orderly Reactivation of Dormant Tumor Suppressor Pathways, Biochemistry, 97, 12513-12518.

Handayani, S., Susidarti, R.A., Jenie, R.I. and Meiyanto, E., 2017, Two Active Compounds From Caesalpinia sappan L. in Combination With Cisplatin Synergistically Induce Apoptosis and Cell Cycle Arrest on WiDr Cells, Advanced Pharmaceutical Bulletin, 7, 375-380.

Heather, S., 2007, What is Sound Healing?, The International Journal of Healing and Caring, 7, 1-11.

Hondermarck, H., 2003, Breast Cancer, When Proteomics Challenges Biological Complexity, Molecular \& Cellular Proteomics 2.5, 2, 281-291.

Ibrahim, M.A., Shah, M.S.M. and Mohd, R.A., 2017, Concept of shifa in Al-Quran: Quranic medicine approach in healing physical ailment. 2nd International Conference on Islam, Science \& Education: University Sains Malaysia.

Ismiyati, N. and Nurhaeni, F., 2016, Basil leaf extract effect (Ocimum sanctum L.) as che- 
mopreventive agent in Hela cervical cancer cells through cytotoxic activity and apoptosis induction, Media Farmasi, 13, 35-48. Istindiah, H.N. and Auerkari, E.I., 2001, Cell cycle control mechanism: a special review of the protein regulator's role in retinoblastoma pathways (Rb), JKGUI, 8, 39-47. Jones, H., Feth, L., Rumpf. D., Hefti, A., Mariotti, A. 2000, Acoustic Energy Affects Human Gingival Fibroblast Proliferation but Leaves Protein Production Unchanged, J Clin Periodontol, 27, 832-838.

Khatoni, A., 1997, The Effect of Reciting the Quran on Anxiety of Patients Hospitalized in the Cardiac Intensive Care Unit of the Selected hospitals in Tehran: Master Thesis, Tehran: J Iran Univ Med Sci, 39, 4-22. Larasati, Y.A., Putri, D.D.P., Utomo, R.Y., Hermawan, A. and Meiyanto, E., 2014, Combination of Cisplatin and Cinnamon Essential Oil Inhibits HeLa Cells Proliferation Through Cell Cycle Arrest, Journal of Applied Pharmaceutical Science, 4, 014-019. Lestard, N.R., Valente, R.C., Lopes, A.G. and Capella, M.A.M., 2013, Direct Effects of Music in Non-Auditory Cells in Culture. Noise and Health, $A$ Bimonthly Inter-Disciplinary International Journal, 15, 307-314. Lestard, N.R. and Capella, M.A.M., 2016, Exposure to Music Alters Cell Viability and Cell Motility of Human Nonauditory Cells in Culture, Evidence-Based Complementary and Alternative Medicine, 2016, 1-7. Maman, F., 1997, The Role of Music in the 21st Century - Book 1, Redondo Beach, CA: Tama-Do Press Mehrafsar, A. and Mokhtari, M.J., 2018, Effect of exposure to Quran recitation on cell viability, cell migration, and BCL2L12 gene expression of human prostate adenocarcinoma cell line in culture, Health, Spirituality and Medical Ethics, 5(4), 46-52.
Murti, H., Boediono, A., Setiawan, B. and Sandra, F., 2007, Cell cycle regulation: key success somatic cell nuclear transfer, CDK, 34, 312-316.

Mustamir, 2008, 5 Healing methods of the heavens, Yogyakarta: Lingkaran.

Nemoto, Y., 2014, Message from Water and Science, The 9th Annual Conference on the Physics, Chemistry, and Biology of Water; Bulgaria, 2014.

Nisyak, K. and Farid, R.M., 2017, Antioxidant and cytotoxic activity of methanol bark extract Cambodian stem (Plumeria acuminate) against cervical cancer cells, Jurnal Tumbuhan Obat Indonesia, 10, 37-44.

Oemiati, R., Rahajeng, E. and Kristanto, A.Y., 2011, The prevalence of tumors and some factors that affect them in Indonesia, Buletin Penelitian Kesehatan, 39, 190-204.

Prabasari, C.I.W. and Budiana, I.N.G., 2017, Profile of cervical cancer in general Hospital Sanglah Denpasar, Bali period July 2012-June 2013, E-Jurnal Medika, 6, 1-9.

Putri, Y.K. and Rusdiana, T., 2016, Comparison of various drug interactions with herbs: Article Review, Farmaka Suplemen, 14, 203-214.

Sayyid, S.A., 2008, The Secret of Al-Fatihah \& Ayat Kursi, Solo: Mumtaza.

Sundarajan, S. and Vogelzang, N., 2014, Chemotherapy in the treatment of prostate cancer - the past, the present, and the future, American Journal of Hematology and Oncology, 10(6), 14-21.

Yudhani, R.D., Pesik, N.R. and Indarto, D., 2016, Metformin Enhances Anti-Proliferative Effect of Cisplatin in Cervical Cancer Cell Line, Indonesian Journal of Clinical Pharmacy, 5, 75-83.

Zhang, M. , Marcela, C., Yang, E. B., Wong, K.P. and Mack, P., 2001, Modulation of cisplatin cytotoxicity and cisplatin-induced DNA cross-links in HepG2 cells by regulation of glutathione-related mechanism, Molecular Pharmacology, 59, 837-843. 